\title{
Socio-economics in forestry
}

\author{
Achim Schlüter $\cdot$ Roderich von Detten
}

Published online: 29 December 2010

(C) Springer-Verlag 2010

When we started to approach scholars to contribute to this special issue in the European Journal of Forest Research about socio-economics in forestry, we already knew that we would receive a collection of papers characterized by a maximum of diversity. This was not by chance: The special issue emerged out of a wish to present a variety of approaches beyond the scope of so-called neoclassical forestry economics, which would focus on the subject of human-forest relations in a wider context-a research programme that lies at the centre of the research agenda of the Institute of Forestry Economics (IFE) of the Faculty of Forestry and Environmental Sciences at Freiburg University (Oesten and Roeder 2002). ${ }^{1}$

Forestry economics, as in economics in general, has for a long time been defined by its particular methodology (Pearse 1990), neoclassical economics, applying a rational actors approach and the assumption of a neoclassical market (Kant 2003). The limitations of these forest economic models and the shortcoming of not explicitly considering economic behaviour in relation to social structures and processes as well as a necessary focus on the contextbounded and culturally rooted human actors' behaviour have been described in detail (Kant and Berry 2005). A narrow understanding of the utility of a 'profit maximizing agent' and a narrow utilization of 'a methodology' will not

This is one in a series of articles dedicated to Prof. Dr. Dr. h.c. Gerhard Oesten on the occasion of his 60th birthday.

A. Schlüter · R. von Detten $(\square)$

Institute of Forestry Economics University of Freiburg,

Tennenbacher Str. 4, 79085 Freiburg, Germany

e-mail: r.v.detten@ife.uni-freiburg.de

URL: www.ife.uni-freiburg.de

A. Schlüter

e-mail: a.schlueter@ife.uni-freiburg.de provide an understanding of the economy of the forest (Oesten 1986). The main consequence of this conclusion is that forestry economics can no longer be defined and understood by the particular methodology it applies, but rather by its subject area. ${ }^{2}$ Despite their differences, the papers in this issue share a focus on the nature of human behaviours and interactions in the context of governing, regulating, using, or interacting with the forest as a natural resource. This research focus is more properly termed as 'socio-economics of forestry' rather than-in a classical term- 'forestry economics', as it clearly indicates that the adoption of a multitude of different methodological approaches and research programmes is necessary to cope with the complexities of social reality.

Socio-economics in forestry can be defined as a research programme beyond neoclassical economics which focuses on analysis of the social interactions behind forest management practices regarding the production, exchange, conservation and distribution of forest-related goods, services and resources. The research subjects encompass market as well as social and political processes. Since a socio-economic approach implies the adoption of a variety of different theories and methods mainly from the social and cultural sciences, this collection of papers reflects a multitude of theories from (institutional) economics, political sciences, sociology, behavioural sciences, management theory and cultural sciences.

The collection and joint publication of such a diverse selection of papers demonstrate that for (forest) scientists who want to reduce the gap between scientific models and

\footnotetext{
$\overline{1}$ See also Oesten et al. (1999) and Oesten and von Detten (2008) for the expansion of the debate on the entire forest science.

2 See Hodgson (2000), who is proposing a similar understanding for economics in general.
} 
practices of forest management (Kant 2003: 40) and create "better accounts of the world" (Haraway 1999, 182), there is no single path for acquiring knowledge. With the strong requirements concerning reliability, validity and particularly transparency, this position does not intend to argue for an "anything goes" mentality within science. However, a diversification and a mutual stimulation of different epistemologies, methodologies and methods are regarded as necessary (Poteete and Ostrom 2008). In this respect, this issue follows Kant's call for "extending the boundaries of forest economics" (2003).

Creating a disciplinary divide between governance mechanisms (i.e. forestry economics is responsible for governing through markets, forest political science is responsible for political governance and forest sociologists are responsible for civil society and community) would not only contradict the definition provided above as to what socio-economics of forestry is about, but it would also, in most cases, be an artificial division: There exists a nonsoluble interdependence among the various governance mechanisms. Markets, political and civil society regulation evolve in a joint process and are mutually influenced. How forestry markets evolve (see e.g. Nichiforel and Schanz 2010; Garrelts and Flitner 2010; Meidinger 2010; Schlüter and Koch 2010, in this issue) is inseparably linked to e.g. the general understanding of common welfare in a society (see Ruppert-Winkel and Winkel 2010), the societal definition of sustainability (see von Detten 2010; Deegen et al. 2010), or other political processes, determining what shall be done, exchanged or distributed within forests (see Domínguez and Shannon 2010).

The papers are organized on a continuum-and there is definitely no single measurement scale that would allow for an unambiguous order-in relation to the governance mechanism primarily analysed. The collection of papers starts with those looking more to the individual entity and the market as governance mechanisms, then moving on to more political and civic governance processes.

In the diversity of the collection of essays, the paper by Hanewinkel, Hummel and Albrecht (2010) most probably represents the traditional approach of forestry economics. This literature review article discusses how the core discipline of forestry economics has dealt with modelling risks in forestry, particularly dealing with the inherent problem of managing forests in the face of risk and uncertainty.

The paper from Deegen, Hostettler and Navarro seems, at first glance, to be located in the heart of classical forestry economics: By further examining the near-legendary Faustmann Formula, the authors, rather uncharacteristically from a forest science perspective, argue in favour of the market as a social-institutional arrangement. Using an evolutionary/Austrian and ordoliberal perspective on forestry, the authors consider markets best suited to determine what is sustainable, as even the best forest manager will never be able to predict what will arise and be valued in the future.

The following two papers consider the same subject, the evolution of institutions governing markets; however, they use different theories and cases. The papers of Nichiforel and Schanz and Schlüter and Koch deepen this aspect of constructedness in two different directions. The paper of Nichiforel and Schanz looks at the rent-seeking strategies of private entrepreneurs with their goal of changing the institutional setting of the Romanian forestry sector. Rentseeking entrepreneurs have different entry points for their rent-seeking activities: the paper discusses the reasons for choosing one or the other mechanism in Romania. Schlüter and Koch look at the emergence of contracts and other property rights in the forestry sector in the German region of Allgäu, Bavaria: Contrary to what economic theories of institutional change would suggest, those contracts do not evolve in the direction of saved transaction costs; instead, the observed change of institutions can be attributed to mental models, positive and normative explanations of the world, which the actors have adopted. The particular role of trust-a concept long negated in economics-has been explored.

The following two papers focus on the civic governance process of forest certification as a particular area of market regulation within forestry. Garrelts and Flitner explore the relation of the Forest Stewardship Council (FSC) to the ecosystem approach as it has developed in the framework of the Convention on Biological Diversity (CBD). Noting a substantial convergence in the broader aims and normative background of the instruments, they ask what lessons could be learned from FSC's experience in developing and implementing norms and standards in a very detailed and practice-oriented manner. While some of the experiences may prove useful for further development and implementation of the ecosystem approach, as they argue with regard e.g. to the decision-making mechanisms, they are more sceptical regarding FSC's suitability as a blueprint in what concerns the alignment of economic incentives with the broader aims that have been originally set out in the development of the instrument.

Then, in his analysis of the FSC and PEFC, Meidinger focuses on the question of democratic legitimisation of the certification scheme. Certification schemes replace governance and regulations, which traditionally have been provided by the state. Certification schemes, however, do prescribe to a certain degree how our global forests are managed and how much of common wealth or common good is produced or destroyed - the question of democracy therefore seems of particular relevance.

The paper of Ruppert \& Winkel looks at the emergence of rules that govern forest resources clearly situated in the 
political arena. As the authors show, it is far too obvious that this political determination also determines what kinds of transactions are allowed in the economic domain. The contribution, which focuses on the definition and regulation of what comprises common welfare in German forests, clearly shows how common welfare is determined by different actors' discourses and story lines. The different actors' views and interpretations of reality (whatever this is in a social context) lead to different story lines when arguing for a particular moulding of common welfare. In their conclusion, the authors underline the importance of actors' relative capabilities that take part in the political process determining what common welfare signifies.

In order to extend the models of economic activities provided by traditional econometric approaches and to contribute to a better understanding of the objectives, motifs and interests behind forest management, Dominguez \& Shannon examine the relevant factors that influence perceptions and active decision-making processes of landowners in Catalonia. Their application of a grounded theory approach results in a description of four often interrelated key factors: besides the specific financial situation of the landowner and the vulnerability of its property to forest fires, there exist strong moral obligations to care for and maintain forests as well as specific personal models of ideal forest that guide decision-making. As the authors argue, the acknowledgement of the existence of such unique combinations of these four variables entails a variety of policy implications, which are discussed in detail.

The article by $v$. Detten deals with a governance issue of particular prominence in the forestry sector, the determination of the concept of sustainability. The author points to the antinomy of the concept of sustainability with its longterm perspective, and the reality of uncertainty, an everchanging future and the lack of genuine knowledge for long-term strategic planning. He argues against the conversion of the normative principle of sustainability into optimizing sustainability strategies and discusses "muddling through" and "adaptive management" strategies and their ability to increase our awareness of uncertainties in order to improve strategic decision-making in environmental management.

The issue closes with the paper by Fortmann and Ballard (2010) who use perspectives from science and technology studies to address research practice at the intersection of biophysical and socio-economic forestry research. The authors demonstrate that contrary to the frequent demarcation between "scientific" and "practitioner" knowledge, integrating practitioners (actors with on-the-ground experience with a forest resource) into the scientific process as researchers (interdependent research) can lead to more rigorous and more accurate research.
What does such a collection of a very different set of papers allow us to conclude? First, the entirety of papers clearly shows the importance of the "social" when considering forests and forestry. How forests develop is largely influenced by the results of the bargaining of actors who have stakes in the forests, whether it is bargaining taking place in the economic or in the political arena. Second, the issue may show that a multitude of various approaches not following the traditional and still dominant deductive research design is fruitful in creating a better understanding of human-environmental interactions, which is the final goal of doing social science research in the area of forestry.

It was a pleasure to live through the collective action process of the discussion around and emergence of the different papers. That is what science is about. All the authors are somehow attached to the Institute of Forestry Economics and the Albert-Ludwigs-University, Freiburg, and therefore to its director Gerhard Oesten, to whom this issue is dedicated on the occasion of his 60th birthday. All authors are grateful for the space and discussions provided around this Institute, which allows for the diversity presented in this issue.

\section{References}

Deegen P, Hostettler M, Navarro GA (2010) The Faustmann model as a model for a forestry of prices. Eur J For Res. doi:10.1007/ s10342-009-0336-9

Domínguez G, Shannon M (2010) A wish, a fear and a complaint: understanding the (dis)engagement of forest owners in forest management. Eur J For Res. doi:10.1007/s10342-009-0332-0

Fortmann L, Ballard H (2010) Sciences, knowledges, and the practice of forestry. Eur J For Res. doi:10.1007/s10342-009-0334-y

Garrelts H, Flitner M (2010) Governance issues in the Ecosystem Approach: what lessons from the Forest Stewardship Council? Eur J For Res. doi:10.1007/s10342-009-0350-y

Hanewinkel M, Hummel S, Albrecht A (2010) Assessing natural hazards in forestry for risk management: a review. Eur J For Res. doi:10.1007/s10342-010-0392-1

Haraway D (1999) Situated knowledges: the science question in feminism and the privilege of partial perspective. In: Biagioli M (ed) The Science studies reader. Routledge, New York, pp 172-188

Hodgson G M (2000) An alternative economics for the new millenium: The Venice Theses' the other canon conference, Venice, January 13-14

Kant S (2003) Extending the boundaries of forest economics. For Policy Econ 5:39-56

Kant S, Berry AR (2005) Sustainability, institutions, and forest management'. In: Kant S, Berry AR (eds) Institutions, sustainability, and natural resources: institutions for sustainable forest management. Springer, Doordrecht, pp 1-20

Meidinger E (2010) Forest certification and democracy. Eur J For Res. doi:10.1007/s10342-010-0426-8

Nichiforel L, Schanz H (2010) Property rights distribution and entrepreneurial rent-seeking in Romanian forestry: a perspective of private forest owners. Eur J For Res. doi:10.1007/s10342009-0337-8 
Oesten G (1986) Über die forstliche Betriebswirtschaftlehre als angewandte Sozialwissenschaft, Freiburg

Oesten G, von Detten R (2008) Zukunftsfähige Forstwissenschaften? Eine Standortbestimmung zwischen Anspruch und Wirklichkeit in sieben Thesen und drei Fragen. Allgemeine Forst und Jagdzeitung 179(8/9):135-141

Oesten G, Roeder A (2002) Management von Forstbetrieben. Remagen-Oberwinter, Kessel

Oesten G, Schanz H, Spies GV (1999) Forstwissenschaft oder Forstwissenschaften: Interdisziplinarität zwischen zwangsläufigkeit, vision und utopie. Forstw Cbl 118:368-380

Pearse P (1990) Forestry economics. University of British Columbia Press, Vancouver

Poteete AR, Ostrom E (2008) Fifteen years of empirical research on collective action in natural resource management: struggling to guild large-N databases based on qualitative research. World Dev 36(1):176-195

Ruppert-Winkel C, Winkel G (2010) Hidden in the woods? Meaning, determining, and practicing of 'common welfare' in the case of the German public forests. Eur J For Res. doi:10.1007/s10342009-0335-x

Schlüter A, Koch M (2010) Institutional change in the forest sector: trust and mental models. Eur J For Res. doi:10.1007/s10342009-0333-Z

von Detten R (2010) Sustainability as a guideline for strategic planning? The problem of long term forest management in the face of uncertainty. Eur J For Res. doi:10.1007/s10342-0100433-9 